\title{
Cloning and characterization of the determinant for abortive infection of bacteriophage from lactococcal plasmid pCI829
}

\author{
Aidan G. Coffey, Gerald F. Fitzgerald* and Charles Daly \\ Food Microbiology Department, University College, Cork, Ireland
}

(Received 22 June 1990; revised 18 January 1991; accepted 20 February 1991)

\begin{abstract}
The genetic determinant for abortive infection of bacteriophage (Abi) from the lactococcal plasmid pCI829 was cloned on a $6.2 \mathrm{~kb}$ StuI fragment in Escherichia coli using the shuttle vector pSA3. In Lactococcus lactis subsp. lactis MG1363Sm the resulting recombinant plasmid pCI816 conferred complete insensitivity to the small isometric-headed phage 712 and a reduced plaque size in the case of the prolate-headed phage $c 2$. The determinant was further localized by subcloning and nuclease Bal31 deletion analysis; approximately $2.0 \mathrm{~kb}$ of DNA was essential for the expression of the $\mathrm{Abi}^{+}$phenotype. Nucleotide sequence analysis of this region revealed a putative open reading frame of 1887 base pairs preceded by a putative promotor sequence and ribosome-binding site which exhibited similarity to consensus $E$. coli and Bacillus subtilis transcription/translation signals. Hybridization experiments indicated that this region was not homologous to the abi determinant from the phenotypically similar lactococcal plasmid pCI750.
\end{abstract}

\section{Introduction}

Production of many cultured dairy products relies on the efficient formation of lactic acid by lactic acid bacteria, including species of the genus Lactococcus. Bacteriophages are a significant cause of inhibition of starter cultures and as a result, phages and phage insensitivity have become a major focus of research interest. Current studies on aspects of phage insensitivity in lactococci have resulted in the identification of several plasmids which inhibit the proliferation of phage. These are discussed in some detail in recent reviews by Klaenhammer (1987, 1989), Daly \& Fitzgerald (1987) and Sanders (1988). Subsequent reports on plasmid-mediated phage insensitivity include those by Josephen \& Vogensen (1989), Murphy et al. (1988), Dunny et al. (1988), Jarvis (1988), Jarvis et al. (1989) and Steele et al. (1989). The insensitivity mechanisms that have been observed include adsorption inhibition, restriction and modification $(\mathrm{R} / \mathrm{M})$ and abortive infection (Abi). Recently, considerable effort has been focussed on the localization of the genetic determinants for phage insensitivity.

The nucleotide sequence data reported in this paper have been submitted to GenBank and have been assigned the accession number M63080.
These efforts have been successful particularly in the case of the plasmid pTR2030, where R/M and abortive infection (designated $\mathrm{Hsp}$ in this case) determinants were cloned on a $13.8 \mathrm{~kb}$ DNA fragment and further localized using $\operatorname{Tn} 5$ mutagenesis and deletion analysis (Hill et al., 1989a,b). Additional reports on the cloning of phage insensitivity determinants include those concerning pCI750 (Steele et al., 1989), pIL105 (Simon \& Chopin, 1988), and pKR223 (McKay et al., 1989). In this laboratory a $27 \mathrm{MDa}$ conjugative plasmid designated pCI829 which encodes Abi has been described (Coffey $e t$ al., 1989). pCI829 was originally transferred by conjugation from Lactococcus lactis subsp. lactis UC811 to the plasmid-free strain L. lactis subsp. lactis MG1363Sm, where it conferred total insensitivity to small isometricheaded phages and a greatly reduced burst size in the case of prolate-headed phages. Plasmid pCI829 was found to be capable of stably co-existing with a derivative of $\mathrm{pCI} 750$ which encodes a similiar phage insensitivity mechanism (Baumgartner et al., 1986). A strain containing both plasmids showed significantly greater insensitivity to phages than did one containing either plasmid on its own (Coffey et al., 1989).

This report describes the cloning, subcloning, nuclease Bal31 treatment and nucleotide sequence analysis of the pCI829-associated genetic determinant for Abi. 
Table 1. Bacterial strains and bacteriophages

\begin{tabular}{|c|c|c|c|}
\hline Strain & $\begin{array}{l}\text { Sensitivity to } \\
\text { phage } 712^{*}\end{array}$ & Plasmid content & Origin/derivation \\
\hline \multicolumn{4}{|c|}{ L. lactis subsp. lactis } \\
\hline MG1363Sm & S† & None & $\begin{array}{l}\mathrm{Sm}^{r} \text { plasmid-free derivative of } L \text {. lactis subsp. lactis } 712 \\
\text { (Gasson, 1983) }\end{array}$ \\
\hline $\mathrm{AC} 002$ & I & pCI829 & $\begin{array}{l}\mathrm{Lac}^{-} \text {derivative of } L \text {. lactis subsp. lactis AC001 } \\
\text { (Coffey et al., 1989) }\end{array}$ \\
\hline AC816 & I & pCI816 & \multirow{8}{*}{$\begin{array}{l}\text { Transformants of L. lactis subsp. lactis MG1363Sm } \\
\text { (this study) }\end{array}$} \\
\hline AC817 & $\mathbf{S}$ & pCI817 & \\
\hline $\mathrm{AC} 815$ & $\mathbf{S}$ & pCI815 & \\
\hline AC813 & $\mathbf{S}$ & pCI813 & \\
\hline $\mathrm{AC} 814$ & $\mathbf{S}$ & $\mathrm{pCI} 814$ & \\
\hline AC812 & $\mathbf{S}$ & $\mathrm{pCI} 812$ & \\
\hline AC8147 & I & $\mathrm{pCI} 8147$ & \\
\hline AC8144 & I & pCI8144 & \\
\hline MMl & $\mathbf{I}$ & pMM1 & \multirow[t]{2}{*}{ Steele et al. (1989) } \\
\hline AC719 & $\mathbf{I}$ & $\mathrm{pB} 719$ & \\
\hline $\mathrm{AC} 718$ & I & $\mathrm{pB} 718$ & \multirow[t]{3}{*}{ Deletion derivatives of $\mathrm{pCI} 147$ (this study) } \\
\hline AC721 & $\mathbf{S}$ & $\mathrm{pB} 721$ & \\
\hline AC408 & I & pB408 & \\
\hline $\mathrm{AC} 426$ & I & $\mathrm{pB} 426$ & \multirow[t]{2}{*}{ Deletion derivatives of pCI8144 (this study) } \\
\hline AC433 & $\mathbf{S}$ & pB433 & \\
\hline \multicolumn{4}{|l|}{ E. coli } \\
\hline $\mathrm{DB} 11(\mathrm{pSA} 3)$ & - & pSA3 & Dao \& Ferretti (1985) \\
\hline HB101 & - & None & Boyer \& Roulland-Dussoix (1969) \\
\hline TG1 & - & pUC18/19 clones & Courtesy of W. deVos, NIZO, Ede, The Netherlands \\
\hline AC 810 & - & pCI810 & Deletion derivative of pCI816 (this study) \\
\hline $\mathrm{AC} 8147$ & - & pCI8147 & \multirow{2}{*}{ Subclones for Bal31 analysis (this study) } \\
\hline AC8144 & - & $\mathrm{pCI} 8144$ & \\
\hline
\end{tabular}

* $S$, sensitive; $I$, insensitive.

$\dagger \mathrm{MG} 1363 \mathrm{Sm}$ also sensitive to phages $\mathrm{c} 2$ and $\mathrm{ml}$.

\section{Methods}

Bacterial strains, bacteriophages and media. The bacterial strains and bacteriophages used in this study are listed in Table 1. Strains of lactococci were routinely grown in M17 medium (Terzaghi \& Sandine, 1975) at $30^{\circ} \mathrm{C}$ with lactose replaced by glucose when necessary (GM17). Strains of Escherichia coli were grown in LB medium (Davis et al., 1980) at $37^{\circ} \mathrm{C}$ with shaking. Solid media contained $1.5 \%(w / v)$ agar (Oxoid no. 3). The antibiotics erythromycin (Em), chloramphenicol $(\mathrm{Cm})$, tetracycline $(\mathrm{Tc})$ and ampicillin $(\mathrm{Ap})$ were added to selective media for strains of $E$. coli at levels of $250,25,12.5$ and $50 \mu \mathrm{g} \mathrm{ml}^{-1}$, respectively. For lactococci, Em was added at $2 \mu \mathrm{g} \mathrm{ml}^{-1}$.

Isolation of plasmid DNA. Large-scale and rapid isolation of plasmid DNA from lactococci was achieved using the method described by Anderson \& McKay (1983). For E. coli, the method of Birnboim \& Doly (1979) was used. Purification of plasmid DNA by caesium chloride/ ethidium bromide buoyant density gradients was performed as described by Maniatis et al. (1982)

Restriction endonuclease analysis, molecular cloning techniques and nucleotide sequence analysis. Restriction endonucleases were purchased from Boehringer. DNA digestion and general cloning procedures were as outlined by Maniatis et al. (1982). Restriction analysis was performed as described previously (Coveney et al., 1987). For Bal31 deletion analysis the plasmids pCI8147 and pCI8144 were linearized at the $B a m H I$ site and treated with various concentrations of the enzyme for $30 \mathrm{~min}$. DNA fragments from recombinant plasmids containing the $a b i$ determinant were cloned in pUC18 or pUC19. The nucleotide sequence was determined by sequencing double-stranded plasmid DNA in two orientations by the dideoxy chain-termination method (Sanger et al., 1977), using the T7 DNA Sequencing Kit (Promega Corp. USA). Synthetic 17-mer DNA primers were prepared on a DNA synthesizer (Beckman model 200A).

Transformation procedures. Strains of E. coli were transformed using the method of Mandel \& Higa (1970). Lactococci were transformed by electroporation using a Gene Pulser apparatus and a pulse controller unit (Bio-Rad). The culture was grown for $15 \mathrm{~h}$ at $21^{\circ} \mathrm{C}$ in GM17 broth and then diluted $(1: 50)$ in fresh broth and grown at $30^{\circ} \mathrm{C}$ for $2.5 \mathrm{~h}$. Cells were harvested by centrifugation at $4{ }^{\circ} \mathrm{C}$, washed twice in ice-cold $10 \%$ $(\mathrm{w} / \mathrm{v})$ sucrose (Sigma), resuspended in 0.05 culture volumes of ice-cold $10 \%$ sucrose and held on ice until required. Up to 0.1 vol. of plasmid DNA solution was thoroughly mixed with $200 \mu$ l of cell suspension in a chilled Gene Pulser cuvette (electrode separation of $2 \mathrm{~mm}$ ). Cells were exposed to a single electric pulse (peak voltage, $2.5 \mathrm{kV}$; capacitance, $25 \mu \mathrm{F}$; resistance $200 \Omega$ ), which generated a peak field strength of $12.5 \mathrm{kV} \mathrm{cm}^{-1}$. Immediately after delivery of the pulse the cells were added to $1 \mathrm{ml} \mathrm{GM} 17$ broth and incubated at $30^{\circ} \mathrm{C}$ for $2 \mathrm{~h}$ before spread-plating on GM17-Em. Colonies were visible after $24 \mathrm{~h}$. 
Detection of clones exhibiting the Abi phenotype. Following ligation and transformation into $E$. coli, recombinant plasmids were purified and transformed into L. lactis subsp. lactis MG1363Sm by electroporation. Lactococcal electro-transformants were grown for 12 to $18 \mathrm{~h}$ at $21^{\circ} \mathrm{C}$ in GM17-Em and challenged with MG1363Sm-specific phages 712 and $c 2$ by the standard plaque assay technique. Plaque sizes were compared to those of the same phages on L. lactis subsp. lactis MG1363Sm containing vector alone and L. lactis subsp. lactis AC002. Plasmid DNA from clones exhibiting insensitivity to phage 712 and a reduction in plaque size with phage $\mathrm{c} 2$ as compared to MG1363Sm was isolated and analysed to verify the presence of pCI829-derived DNA.

Southern hybridization. DNA was restricted with the appropriate restriction enzyme, electrophoresed on $0.8 \%$ agarose gels, transferred to nitrocellulose filters by the method of Southern (1975) as modified by Wahl et al. (1979), and hybridized with plasmid DNA labelled with digoxigenin-dUTP. After hybridization to the target DNA using highstringency procedures, the hybrids were detected by enzyme-linked immunoassay using an antibody conjugate and subsequent enzymecatalysed colour reaction. All components and protocols were as suggested by the suppliers (Boehringer).

\section{Results}

\section{Localization of determinants encoding Abi on pCI829}

To facilitate genetic analysis of the pCI829-associated phage insensitivity mechanism, attempts were made to localize the genetic determinants for Abi. L. lactis subsp. lactis AC002 was used as a source of pCI829. This plasmid (see the upper part of Fig. 3) was mapped with a number of restriction enzymes, some of which were subsequently used to clone fragments into various $E$. coli-L. lactis shuttle vectors. When pCI829 was digested with StuI, fragments of approximately 37 and $6.2 \mathrm{~kb}$ were generated. These fragments were mixed with pSA3 which had been linearized with $\mathrm{NruI}$ and the ligation mix transformed into E. coli HB101. Analysis of transformants did not yield recombinant plasmids containing the larger of the two fragments. However, a large number of transformants contained a plasmid of $16.4 \mathrm{~kb}$ which was subsequently identified as pSA 3 containing a $6.2 \mathrm{~kb}$ insert originating from pCI829. Further restriction analysis showed that this insert was present in both orientations in various isolates of the $16.4 \mathrm{~kb}$ plasmid. Following electroporation into L. lactis subsp. lactis MG1363Sm, this plasmid was found to mediate the inhibition of replication of phages $c 2$ and 712 irrespective of insert orientation; a representative plasmid was designated pCI816.

\section{Characterization of Abi on pCI816}

The pCI816-containing strain, designated L. lactis subsp. lactis AC816 was compared with MG1363Sm (containing pSA3) and AC002 (containing pCI829) with regard to sensitivity to phages $\mathrm{c} 2$ and 712 . The presence of pSA3

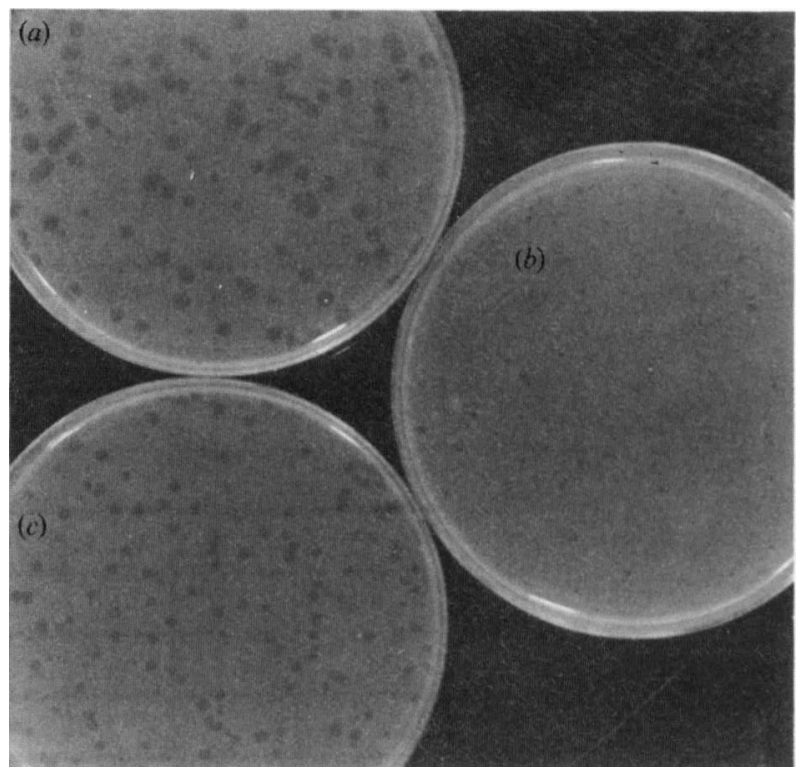

Fig. 1. Comparison of plaque morphology of phage $\mathrm{c} 2$ on L. lactis subsp. lactis MG1363Sm (a), L. lactis subsp. lactis AC002 containing pCI829 (b), and L. lactis subsp. lactis AC816 containing pCI816 (c).

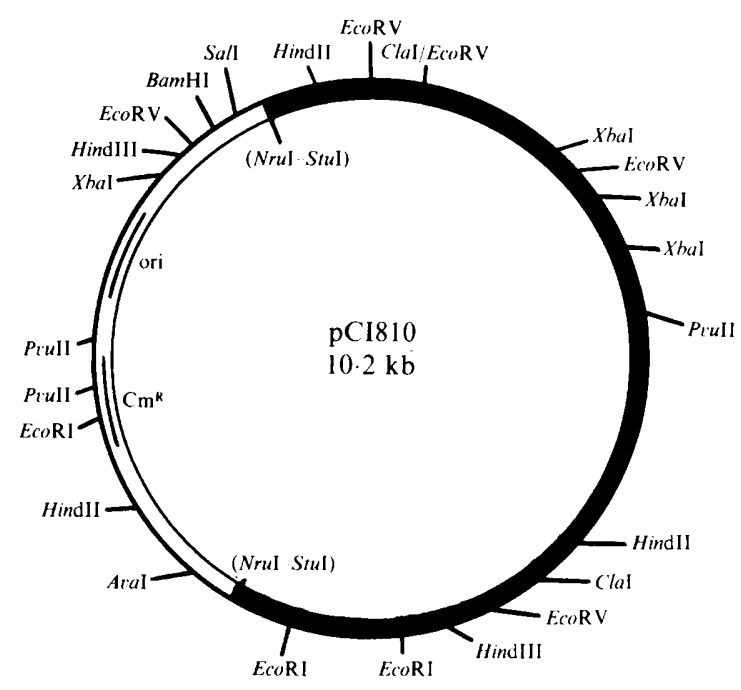

Fig. 2. Restriction map of pCI810, the deletion derivative of pCI816. DNA from pCI829 is shown in black. The remainder is pACYC184 DNA. The junction sites, NruI and StuI, are indicated.

alone in MG1363Sm did not affect phage replication. With phage 712 , MG1363Sm exhibited plaques $0.5 \mathrm{~mm}$ in diameter. This phage failed to form plaques on either AC002 or AC816 although in the case of the latter strain there was some slight inhibition of growth on the $10^{\circ}$ and $10^{-1}$ dilutions in the plaque assay when a phage stock of $10^{8}$ to $10^{9}$ p.f.u. $\mathrm{ml}^{-1}$ was used. Phage $\mathrm{c} 2$ produced plaques of 3.0 to $3.5 \mathrm{~mm}$ on MG1363Sm, $0.5 \mathrm{~mm}$ on AC002 and 1.0 to $1.5 \mathrm{~mm}$ on AC816 (Fig. 1). There was 


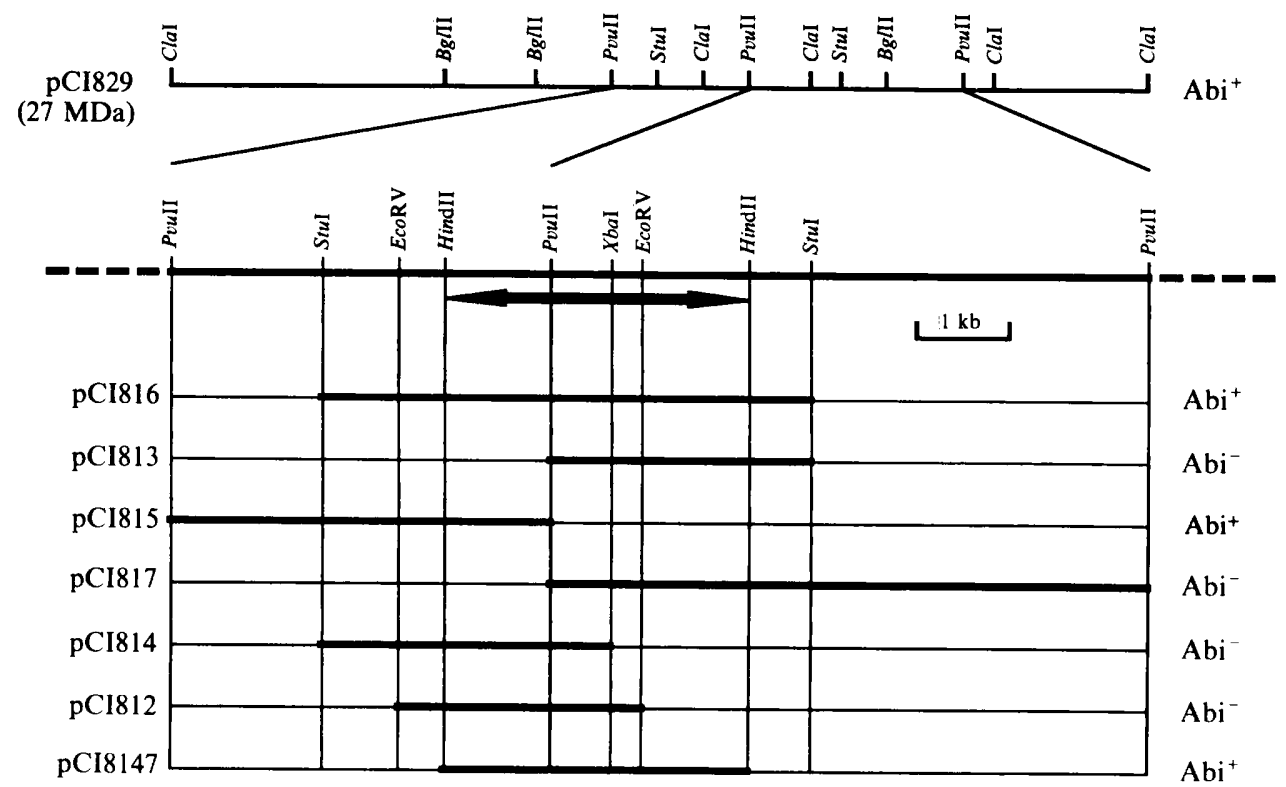

Fig. 3. Restriction map of pCI829. Subclones and their origins are shown underneath. All recombinant plasmids were made using vector pSA3 and insert DNA from either pCI829 or pCI810. Phenotypes $\left(\mathrm{Abi}^{+}\right.$or $\left.\mathrm{Abi}^{-}\right)$are shown on the right. The approximate location of the abi gene is indicated by the arrow underneath the line showing the restriction enzymes used in the clonings.

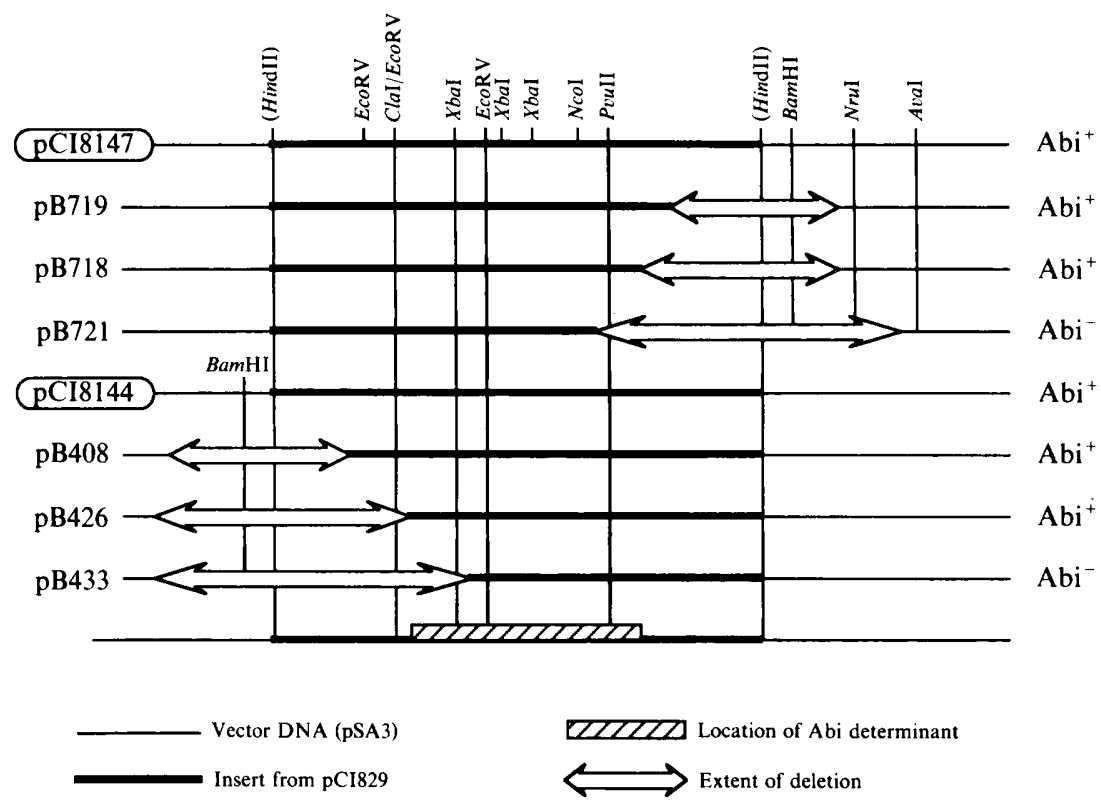

Fig. 4. pSA3 containing the $3.8 \mathrm{~kb}$ HindII insert giving rise to pCI8147 or pCI8144 depending on insert orientation. DNA deleted by nuclease Bal31 from the insert is indicated by the arrows.

no significant reduction in efficiency of plaquing (e.o.p.) with AC816. This contrasts with the observation made in the case of $\mathrm{ACO02}$, where phage c2 plaqued with an e.o.p. of $5.2 \times 10^{-2}$ (Coffey et al., 1989). These data showed that the level of phage insensitivity conferred by pCI816 was not as strong as that conferred by the original plasmid pCI829.

\section{Subcloning of $a b i$}

A closer estimation of the location of the abi determinant was achieved by carrying out a number of subcloning experiments. Before mapping the $6.2 \mathrm{~kb}$ insert in pSA3 the Gram-positive part of the vector was eliminated using AvaI [pSA3 is composed of pACYC184 with a 


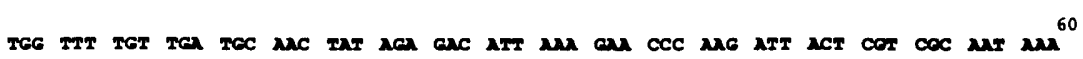

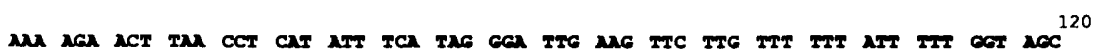

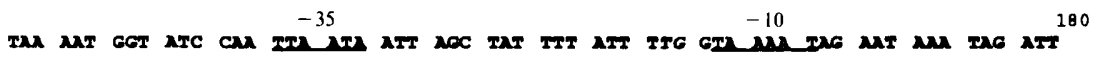

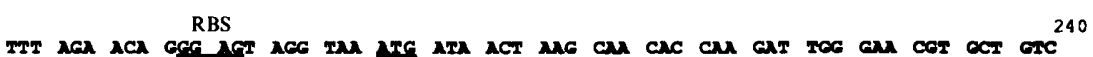

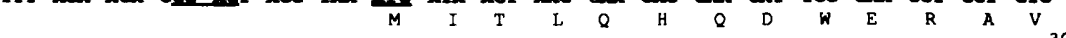

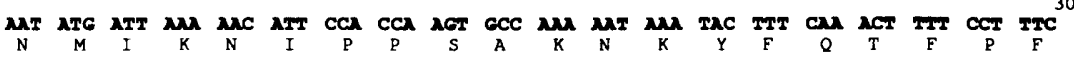

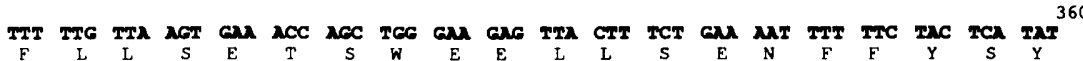

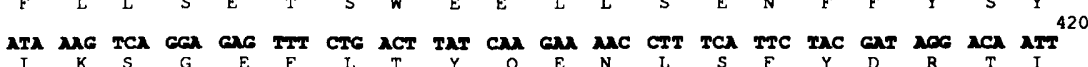
$\begin{array}{llllllllllllllllllllll}I & K & S & G & E & F & L & T & Y & Q & E & N & L & S & F & Y & D & R & T & I & 480\end{array}$

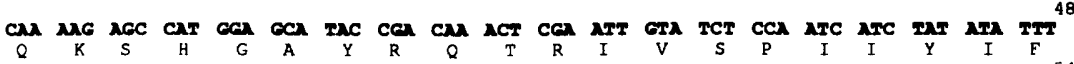

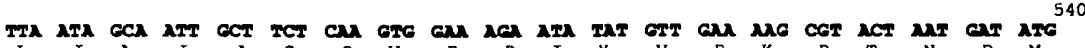

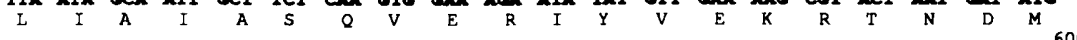

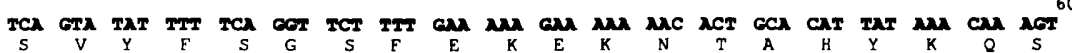

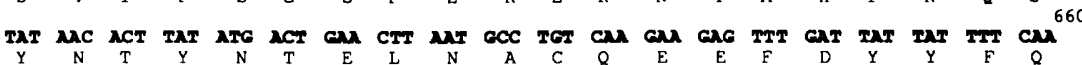

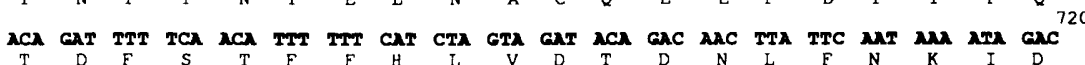

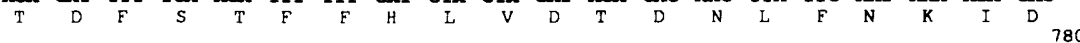

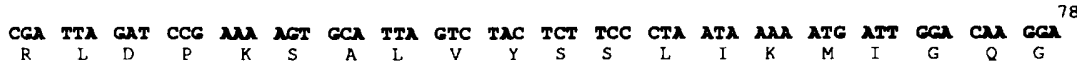
$\begin{array}{lllllllllllllllllllll}R & L & D & P & K & S & A & L & V & Y & S & S & L & I & K & M & I & G & Q & G & \end{array}$

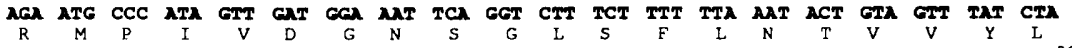

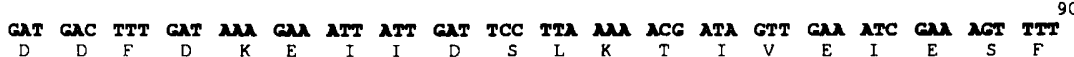

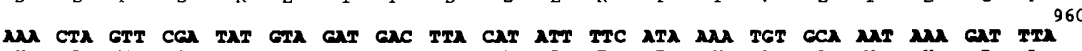

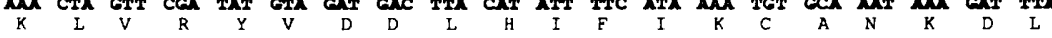

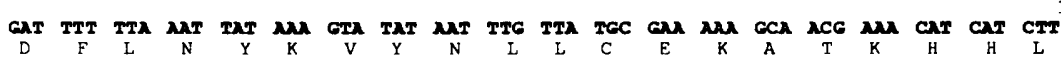

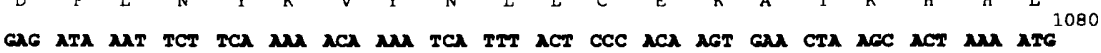

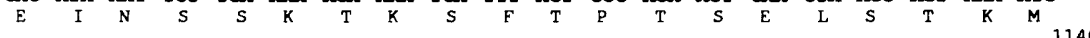

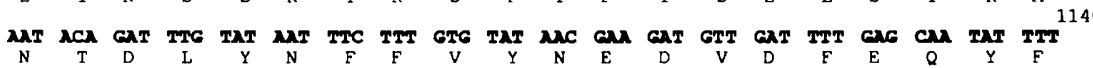

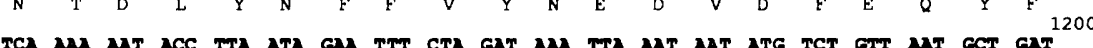

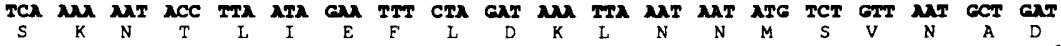

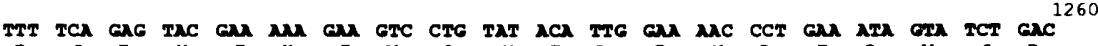

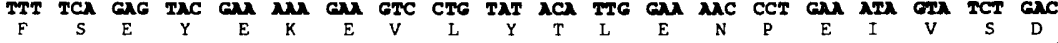

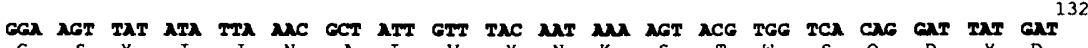

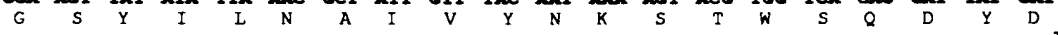

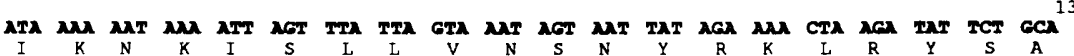

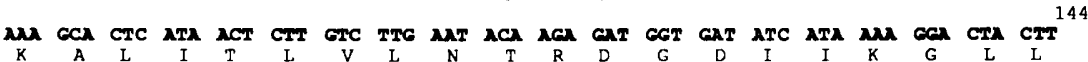
$\begin{array}{llllllllllllllllllll}K & A & L & I & T & L & V & L & N & T & R & D & G & D & I & I & K & G & L & L \\ 1500\end{array}$

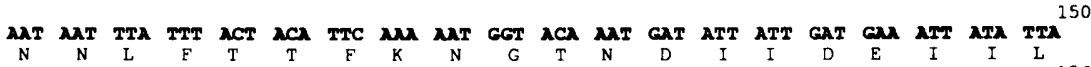

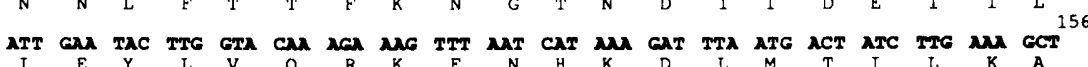
GAC GAC CAT GGT ATT NAG GM TAT ATT NAC GCA TAT CAA ACT TCY GAT TTC ATA NMA AGT

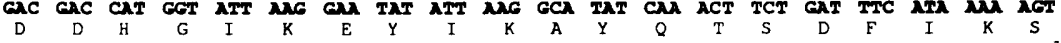

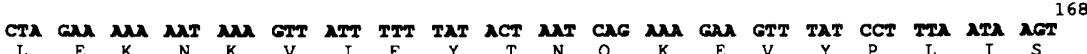

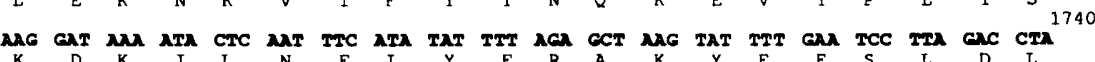

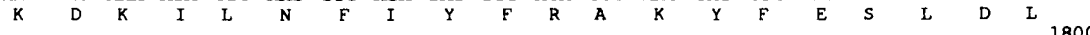

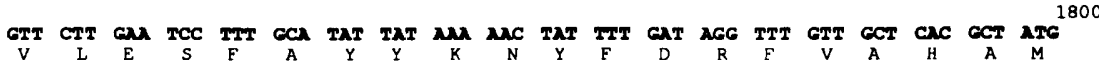

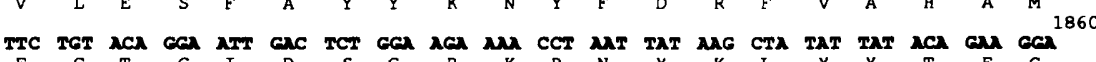
$\begin{array}{llllllllllllllllllll}F & C & T & G & I & D & S & G & R & K & P & N & Y & K & L & Y & Y & T & E & G \\ 1920\end{array}$

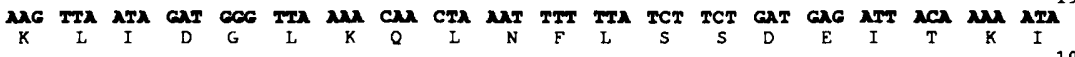

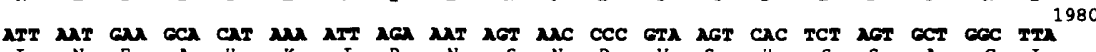

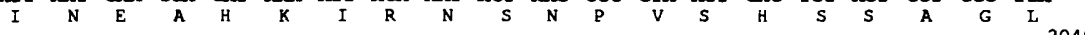

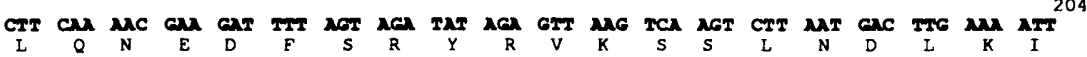

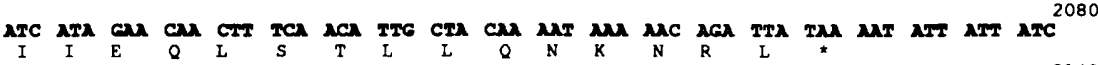

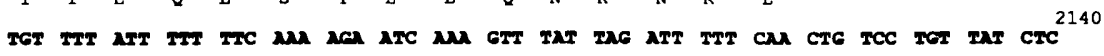

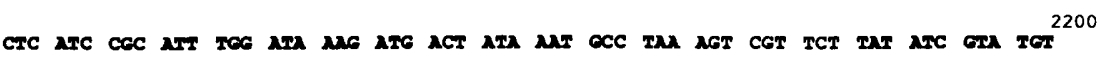

Fig. 5. Nucleotide sequence of the abi region of pCI829. The putative promotor regions, -10 and -35 , and the putative ribosomebinding site (RBS) are underlined. The deduced amino acid sequence is denoted by the single-letter code. 
fragment of the streptococcal plasmid pGB305 inserted into the AvaI site (Dao \& Ferretti, 1985)]. The resulting $10.2 \mathrm{~kb}$ plasmid, designated pCI810, is equivalent to pACYC184 containing the $6.2 \mathrm{~kb}$ StuI fragment (Fig. 2). Various fragments within or overlapping the $6.2 \mathrm{~kb}$ insert of pCI810 were subcloned into pSA 3 and resulting recombinant plasmids were transformed into MG$1363 \mathrm{Sm}$ and assessed for their ability to mediate a reduction in plaque size of phage c2. MG1363Sm containing pCI8147, which is pSA3 containing a $3.8 \mathrm{~kb}$ HindII fragment, exhibited the same level of phage insensitivity as a strain containing pCI816 (Fig. 3). When the $3.8 \mathrm{~kb}$ fragment was present in the opposite orientation (pCI8144) the phenotype was unchanged (Fig. 4).

\section{Bal3I deletion analysis of $p C I 8147$ and pCI8144}

The exact location of the $a b i$ determinant was identified using nuclease Bal31. In the case of pCI8147 it was observed that when deletions included the PvuII site the resulting plasmid reverted to an $\mathrm{Abi}^{-}$phenotype. Examination of one deletion derivative, pB718 (Fig. 4), indicated that up to $0.2 \mathrm{~kb}$ outside the $P v u I I$ site was part of the $a b i$ determinant. Using the plasmid with the insert in the reverse orientation (pCI8144) for deletion analysis it was observed that the $a b i$ gene did not extend to the ClaI site (Fig. 4, pB426). The remaining $2.0 \mathrm{~kb}$ of insert DNA must therefore be essential for expression of Abi.

\section{Nucleotide sequence analysis of the abi region}

The nucleotide sequence of the DNA from the region implicated in Abi by Bal31 deletion analysis was determined. Examination of the sequence indicated the presence of a potential open reading frame (ORF) of 1887 base pairs beginning with an ATG codon at position 202 and ending at a TAA codon at position 2086 and which was capable of encoding a peptide of $73.8 \mathrm{kDa}$ (Fig. 5). The ORF was preceded by a putative promotor sequence and ribosome-binding site which exhibited similarity to consensus $E$. coli and Bacillus subtilis transcription/translation signals manifested by a -35 region in which four of the six nucleotides conformed to the canonical sequence and a -10 region where five of the six conformed. In addition, the -10 region was preceded by a TG sequence frequently observed in lactococcal promotors (van der Vossen et al., 1987).

\section{Hybridization against pMM1}

A number of plasmids which are phenotypically similar to $\mathrm{pCI} 829$ have been identified in various laboratories worldwide. Consequently, it is of interest to determine the degree of homology which may exist between their $a b i$ determinants. Hence the relationship between pCI829 and the previously described phage insensitivity plasmid pCI750 (Baumgartner et al., 1986; Coffey et al., 1989) was examined. The recombinant plasmid pMM1 is composed of the vector plasmid pGB301 and 1.8 and $13.9 \mathrm{~kb} \mathrm{BclI}$ fragments from pCI750. The $13.9 \mathrm{~kb}$ fragment has been indicated by Steele et al. (1989) to contain the abi determinant. The relatedness between the pCI829- and pCI750-derived abi loci was examined in this study by hybridization analysis in which pMM1 digested with either $B c I I$ or $E c o$ RV was probed with two pCI829-derived intergenic abi DNA segments. Hybridization was only observed in lanes containing control digests of pCI816 and no homology was detected with any of the pMM1-derived DNA fragments (data not shown).

\section{Discussion}

The conjugative plasmid pCI829 mediates temperatureindependent phage insensitivity by an abortive infection mechanism which confers complete resistance to small isometric-headed phages and partial insensitivity to prolate phages (Coffey et al., 1989). The phage insensitivity associated with pCI829 appears to be similar to many other abortive phage infection systems described previously (Sanders, 1988).

Recently, the cloning of a number of these Abi systems which appear to be mechanistically similiar to pCI829 has been described (Hill et al., 1989 b, McKay et al., 1989) and since these have been introduced into the closely related plasmid-free $L$. lactis subsp. lactis strains MG1363 or LM0230, it is possible to perform a comparative analysis of the effect of the cloned DNA on the phage sensitivity of the host to the $712 / \mathrm{c} 2$ group of phages. Approximately $2.0 \mathrm{~kb}$ of DNA was essential to confer the phage insensitivity phenotype of pCI829. Examination of the nucleotide sequence of this region did not indicate the presence of any strongly hydrophobic domains, suggesting that the pCI829-associated $a b i$ encodes what would appear to be a cytosolic protein.

In the case of $\mathrm{pCI} 750$ the phage insensitivity determinants were cloned on a $13.9 \mathrm{~kb} B c / \mathrm{I}$ fragment using the streptococcal vector pGB301, giving rise to the recombinant plasmid pMM1 (Steele et al., 1989). Analysis of the physical map of this $13.9 \mathrm{~kb}$ region showed that it did not have any restriction sites in common with the Abiencoding region of $\mathrm{pCI} 829$, suggesting that they are physically unrelated (unpublished data). The same is true for the Abi system cloned from pKR223 (Laible et al., 1987). However, comparison of the nucleotide sequence of the pCI829-associated Abi to that of $h s p$ from 
pTR2030 (Hill et al., 1990) indicates that these two genes are identical. This is interesting, as it shows that this gene may be widely disseminated both geographically and also in different host backgrounds, as strains ME2 and UC811 have distinct plasmid profiles (Klaenhammer \& Sanozky, 1985; Coffey et al., 1989). Neither the abi gene nor the predicted protein product showed any homology to any other existing sequence data in the GenBank database.

The phage insensitivity phenotypes exhibited by lactococcal transformants harbouring plasmids containing either the $6.2 \mathrm{~kb} \mathrm{StuI}$ or the $3.8 \mathrm{~kb}$ HindII fragment or plasmids treated with Bal31 were similar to those observed with a strain containing pCI829: insensitivity against small isometric phages was total (no plaques) and there was a reduction in plaque size for prolate phages, although this reduction was not as marked as that observed with a strain harbouring the complete pCI829 plasmid. It is interesting to note also that the reduction in e.o.p. mediated by pCI829 $\left(5 \cdot 2 \times 10^{-2}\right)$ was not evident in the case of the recombinant plasmids pCI816 or pCI8147. This slightly lower level of expression by the latter plasmids may be due to the fact that the vector used has a lower copy number than pCI829. A decreased level of expression by abi determinants when cloned from their original plasmid has also been observed in the case of pCI750 (unpublished data). A marked difference in the level of expression between pKR223 and pGKB17 has not been reported (McKay et al., 1989): both plasmids reduced the plaque size of phage $\mathrm{c} 2$ from $2 \cdot 3$ $\mathrm{mm}$ to pinpoint. Because of the minute size of these plaques it was not possible to compare the e.o.p. values for strains containing either of these plasmids (Laible $e t$ al., 1987; McKay et al., 1989). However, the drastic reduction in plaque size mediated by either of these plasmids contrasts with our findings for pCI816.

It is probable that many of the Abi systems reported by different laboratories are mediated by closely related genetic determinants. Indeed, a recent report by Steele $e t$ al. (1989) suggested that a degree of homology existed among a number of these plasmids. However, not all of the plasmids encoding this type of phage resistance showed homology to the rather large $13.9 \mathrm{~kb}$ probe which contained the determinants for reduced bacteriophage sensitivity (Rbs) from pCI750. In our laboratory no homology was detected when $1.0 \mathrm{~kb}$ and $0.3 \mathrm{~kb}$ fragments from within the abi region of pCI829 were probed against the $13.9 \mathrm{~kb} B c l \mathrm{I}$ fragment of pMM1, demonstrating that these two plasmids encode physically distinct but phenotypically similar mechanisms of phage insensitivity.

This report highlights some of the recent advances made in the genetic analysis of such a commercially significant trait as phage insensitivity. However, a continued research effort is needed to improve understanding of the interactions between phage and host at the molecular level. An increased knowledge in this area will maximize the potential to eliminate the phage problem in dairy fermentations.

This work was supported by the European Community Biotechnology Action Programme (contract no. BAP-0008-IRL). We acknowledge the suggestion by $T$. R. Klaenhammer to use vector pSA3 in the initial cloning experiments.

\section{References}

ANDERson, D. G. \& MCKAY, L. L. (1983). Simple and rapid method for isolating large plasmid DNA from lactic streptococci. Applied and Environmental Microbiology 46, 549-552.

Baumgartner, A. M., Murphy, M., Daly, C. \& Fitzgerald, G. F. (1986). Conjugative co-transfer of lactose and bacteriophage resistance plasmids from Streptococcus cremoris UC653. FEMS Microbiology Letters 35, 233-237.

BIRnboim H. C. \& Doly, J. (1979). A rapid alkaline extraction procedure for screening recombinant plasmid DNA. Nucleic Acids Research 7, 1513-1523.

BOYER, H. W. \& Roulland-Dussoix, D. (1969). A complementation analysis of the restriction and modification of DNA in Escherichia coli. Journal of Molecular Biology 41, 459-472.

Coffey, A. G., FitzGerald, G. F. \& Daly, C. (1989). Identification and characterisation of plasmid encoding abortive infection from Lactococcus lactis ssp. lactis UC811. Netherlands Milk and Dairy Journal 43, 229-244.

Coveney, J. A., Fitzgerald, G. F. \& Daly, C. (1987). Detailed characterisation and comparison of four lactic streptococcal bacteriophage based on morphology, restriction mapping, DNA homology and structural protein analysis. Applied and Environmental Microbiology 53, 1439-1447.

Daly, C. \& FitzGerald, G. F. (1987). Mechanisms of bacteriophage insensitivity in the lactic streptococci. In Streptococcal Genetics, pp. 923-927. Edited by J. Ferretti \& R. Curtiss. Washington, DC: American Society for Microbiology.

Davis, R. W., Botstein, D. \& Roth, J. R. (1980). Advanced Bacterial Genetics, pp. 140-141. Cold Spring Harbor, NY: Cold Spring Harbor Laboratory.

Dao, M. L. \& FerretTI, J. J. (1985). Streptococcus-Escherichia coli shuttle vector pSA3 and its use in cloning of streptococcal genes. Applied and Environmental Microbiology 49, 115-119.

Dunny, G. M., Krug, D. A., Pan, C.-L., \& Ledford, R. A. (1988). Identification of cell wall antigens associated with a large conjugative plasmid encoding phage resistance and lactose fermentation ability in lactic streptococci. Biochimie 70, 443-450.

Gasson, M. J. (1983). Plasmid complements of Streptococcus lactis NCDO712 and other lactic streptococci after protoplast induced curing. Journal of Bacteriology 154, 1-9.

Hill, C., Pierce, K. \& Klaenhammer, T. R. (1989a). The conjugative plasmid pTR2030 encodes two bacteriophage defense mechanisms in lactococci, restriction modification $\left(\mathrm{R}^{+} / \mathbf{M}^{+}\right)$and abortive infection $\left(\mathrm{Hsp}^{+}\right)$. Applied and Environmental Microbiology 55, 24162419.

Hill, C., Romero, D. A., McKenney, D. S., Finer, K. R. \& KLAENHAMmer, T. R. (1989b). Localisation, cloning and expression of genetic determinants for bacteriophage resistance from the conjugative, bacteriophage resistance plasmid pTR2030. Applied and Environmental Microbiology 55, 1684-1689.

Hill, C., Miller, L. A. \& Klaenhammer, T. R. (1990). Nucleotide sequence and distribution of the pTR2030 resistance determinant ( $h s p$ ) which aborts bacteriophage infection in lactococci. Applied and Environmental Microbiology 56, 2255-2258. 
JARVIS, A. W. (1988). Conjugal transfer in lactic streptococci of plasmid-encoded insensitivity to prolate- and small isometric-headed bacteriophages. Applied and Environmental Microbiology 54, 777-783.

Jarvis, A. W., Heap, H. A. \& Limsowtin, G. K. Y. (1989). Resistance against industrial bacteriophages conferred on lactococci by plasmid pAJ1106 and related plasmids. Applied and Environmental Microbiology 55, 1537-1543.

JOSEPHEN, I. \& VOGENSEN, F. K. (1989). Identification of three different plasmid-encoded restriction/modification systems in Streptococcus lactis subsp. cremoris W56. FEMS Microbiology Letters 59, 161-166.

Klaenhammer, T. R. (1987). Plasmid-mediated mechanisms for bacteriophage defense in lactic streptococci. FEMS Microbiology Reviews 46, 313-325.

KlaENHAMmeR, T. R. (1989). Genetic characterisation of multiple mechanisms of phage defense from a prototype phage-insensitive strain, Lactococcus lactis ME2 Journal of Dairy Science 72, 34293443.

Klaenhammer, T. R. \& SANOzKy R. B. (1985). Conjugal transfer from Streptococcus lactis ME2 of plasmids encoding phage resistance, nisin resistance and lactose fermenting ability: evidence for a high frequency conjugative plasmid responsible for abortive infection of virulent bacteriophage. Journal of General Microbiology 131, 15311541 .

Laible, N. J., Rule, P. L ., Harlander, S. K. \& McKay, L. L. (1987). Identification and cloning of plasmid deoxyribonucleic acid coding for abortive phage infection from Streptococcus lactis ssp. diacetylactis KR2. Journal of Dairy Science 70, 2211-2219.

Mandel, M. \& HigA, A. (1970). Calcium-dependent bacteriophage DNA infection. Journal of Molecular Biology 53, 154-168.

Maniatis, T., Fritsch, E. F. \& SAMbrooK, J. (1982). Molecular Cloning. A Laboratory Manual. Cold Spring Harbor NY: Cold Spring Harbor Laboratory.

McKay, L. L., Bohanon, M. J., Polzin, K. M., Rule, P. L. \& BALDWIN, K. A. (1989). Localization of separate genetic loci for reduced sensitivity towards small isometric-headed bacteriophage sk1 and prolate-headed bacteriophage c2 on pGBK 17 from Lactococcus lactis subsp. lactis KR2. Applied and Environmental Microbiology 55, 2702-2709.

Murphy, M. C., Steele, J. L., Daly, C. \& McKay, L. L. (1988). Concomitant conjugal transfer of reduced bacteriophage sensitivity mechanisms with lactose- and sucrose-fermenting ability in lactic streptococci. Applied and Environmental Microbiology 54, 1951-1956.

SANDERS, M. E. (1988). Phage resistance in lactic acid bacteria. Biochimie 70, 411-422.

SANGER, F. S., NickLEN, S. \& Coulsen, A. R. (1977). DNA sequencing with chain-terminating inhibitors. Proceedings of the National Academy of Sciences of the United States of America 74, 5463-5467.

Simon, D. \& ChOPIN, A. (1988). Construction of a vector plasmid family and its use for molecular cloning in Streptococcus lactis. Biochimie 70, 559-566.

SOUTHERN, E. M. (1975). Detection of specific sequences among DNA fragments separated by gel electrophoresis. Journal of Molecular Biology 98, 503-517.

Steele, J. L., Murphy, M. C., Daly, C. \& McKay, L. L. (1989). DNA-DNA homology among lactose and sucrose-fermenting transconjugants from Lactococcus lactis strains exhibiting reduced bacteriophage sensitivity. Applied and Environmental Microbiology $55,2410-2413$.

TERZAGHI, B. E. \& SANDINE, W. E. (1975). Improved medium for lactic streptococci and their bacteriophages. Applied Microbiology 29, 807813

VAN Der Vossen, J. M. B. M., VAN Der Lelie \& Venema, G. (1987). Isolation and characterisation of $\mathrm{Wg} 2$ specific promotors. Applied and Environmental Microbiology 53, 2452-2457.

WAHL, G., STERN, M. \& StaRK, G. R. (1979). Efficient transfer of large DNA fragments from agarose gels to diazobenzylomethyl paper and rapid hybridisation using dextran sulfate. Proceedings of the National Academy of Sciences of the United States of America 76, 3683-3687. 